\title{
PERANAN PEREMPUAN PEDAGANG HORTIKULTURA DALAM KELUARGA DI KECAMATAN MODOINDING
}

\author{
Fitia Karolina Tungka \\ Melsje Yellie Memah \\ Melissa Lady Gisela Tarore
}

Naskah diterima melalui Website Jurnal Ilmiah agrisosioekonomi@unsrat.ac.id

Senin, 18 Mei 2020

Disetujui diterbitkan

Jumat, 29 Mei 2020

\begin{abstract}
This study aims to determine the extent of the role of women as wage earners in the family as horticulture traders in Modoinding Sub-District. This research was conducted in October 2019 until January 2020. The data used in this study are primary and secondary data. Sample selection method used the purposive sampling. Primary data collection was obtained through direct interviews using a questionnaire to 13 respondents, who are married, still have a husband and are a native of Modoinding. Secondary data were obtained from literature, official sources from related institutions, and other sources related to this research. Data analysis used the calculation of wife's income as horticultural traders, husband and children. The results showed that, the income of women horticultural traders could add to the economy in the family. The income earned by women horticultural traders per month is IDR. 1,500,000 up to IDR. 5,500,000, - with work time per day from 8 hours to 17 hours. More income was generated from the wife's income as a trader with more time spent by the wife than the husband. So it can be said that the wife is the main breadwinner in the family. The research was $60 \%$ of children with income less than IDR. 2,000,000 - Income of more than IDR. 2,000,001 to IDR. 3,000,000 a month wass 20\%, and income above IDR. 4,000,001 a month was $20 \%$. ${ }^{* \text { eprm } *}$
\end{abstract}

Keywords: role, women traders, horticulture

ABSTRAK

Penelitian ini bertujuan untuk mengetahui seberapa besar peranan perempuan sebagai pencari nafkah dalam keluarga dengan berdagang hortikultura di Kecamatan Modoinding. Penelitian ini dilaksanakan pada bulan Oktober 2019 sampai dengan Januari 2020. Data yang digunakan dalam penelitian ini berupa data Primer dan Sekunder. Pengambilan sampel menggunakan metode secara sengaja (purposive sampling). Pengumpulan data primer diperoleh melalui wawancara langsung dengan menggunakan kuesioner kepada 13 responden, yang sudah berkeluarga, masih mempunyai suami dan merupakan penduduk asli Modoinding. Data Sekunder diperoleh dari pustaka, sumber resmi dari instansi terkait, serta sumber-sumber lain yang berkaitan dengan penelitian ini. Analisis data menggunakan perhitungan pendapatan isteri sebagai pedagang holtikultura, suami dan anak. Hasil penelitian menunjukkan bahwa, pendapatan perempuan pedagang hortikultura dapat menambah perekonomian dalam keluarga. Pendapatan yang di dapat perempuan pedagang hortikultura per bulan sebesar Rp.1.500.000.- sampai dengan Rp. 5.500.000,- dengan waktu kerja per hari dari 8 jam sampai dengan 17 jam. Pendapatan yang lebih banyak itu dihasilkan dari pendapatan istri sebagai pedagang dengan waktu yang digunakan istri lebih banyak dibandingkan dengan suami. Jadi dapat di katakan bahwa istri itu sebagai pencari nafkah utama dalam keluarga. Ditemukan 60\% anak dengan pendapatan kurang dari Rp. 2.000.000,- Pendapatan lebih dari Rp. 2.000.001 sampai Rp. 3.000.000 sebulan sebanyak 20\%, pendapatan di atas 4.000 .001 sebulan sebanyak $20 \%{ }^{*}{ }^{\text {eprm* }}$

Kata kunci: peranan, perempuan pedagang, hortikultura 


\section{PENDAHULUAN}

\section{Latar Belakang}

Sektor pertanian dalam perannya sebagai penyedia bahan pangan yang merupakan salah satu kebutuhan pokok manusia. Sektor pertanian sebagai salah satu sektor yang andal dan mempunyai potensi besar untuk berperan sebagai pemicu pemulihan ekonomi nasional (Husodo dkk, 2004). Sebagai Negara agraris, Pemerintah Indonesia masih menitikberatkan pembangunannya pada sektor pertanian (Luthfi, 2010). Provinsi Sulawesi Utara merupakan salah satu provinsi dengan tingkat pendapatan ekonomi dari sektor pertanian yang cukup tinggi. Salah satu daerah yang mempunyai potensi di bidang pertanian adalah kabupaten Minahasa Selatan. Potensi pertanian di Kabupaten Minahasa Selatan dengan ketersediaan lahan yang subur dan cocok untuk pengembangan berbagai jenis komoditas pertanian. Ketersediaan lahan yang ada saat ini juga relatif luas untuk pengembangan sektor pertanian. Seperti di wilayah Modoinding sebagai sentra hortikultura Minahasa Selatan, bahwa sudah sejak lama Modoinding dikenal sebagai penghasil sayuran kualitas bagus. Berbagai komoditas, seperti kentang, kol, dan sawi dihasilkan dari daerah ini. Pada sektor pertanian, Agribisnis Hortikultura yang meliputi komoditas sayuran, buah-buahan dan tanaman hias (Bambang Irawan, 2012). Hortikultura (horticulture) berasal dari bahasa latin, yaitu hortus yang berarti kebun dan colere yang berarti menumbuhkan (terutama sekali mikroorganism) pada suatu medium buatan. Secara harafiah, hortikultura berarti ilmu yang mempelajari pembudidayaan tanaman kebun. Akan tetapi, pada umumnya para pakar mendefinisikan hortikultura sebagai ilmu yang mempelajari budidaya tanaman sayuran, buahbuahan, bunga-bungaan atau tanaman hias (Zulkarnain, 2014).

Peran menurut Soekanto (2009) adalah proses dinamis dari kedudukan (status). Apabila seseorang melaksanakan hak dan kewajibannya sesuai dengan kedudukannya, dia menjalankan suatu peranan. Perbedaan antara kedudukan dengan peranan adalah untuk kepentingan ilmu pengetahuan. Keduanya tidak dapat dipisahpisahkan karena yang satu tergantung pada yang lain dan sebaliknya. Sedangkan menurut Merton (Dalam Raho, 2007) bahwa peran didefinisikan sebagai pola tingkah laku yang diharapkan masyarakat dari orang yang menduduki status tertentu. Menurut Astuti, (2013) Peran adalah keikutsertaan individu atau kelompok dalam suatu kegiatan guna mencapai tujuan individu maupun tujuan bersama. Peran yang terdapat antara pria dan wanita itu tidak dapat ditentukan karena antara keduanya terdapat perbedaan biologis dan kodrat, tetapi dibedakan atau dipilih-pilih menurut kedudukan, fungsi dan peranan masing-masing dalam berbagai bidang kehidupan dan pembangunan. Pembangunan sektor pertanian di pedesaan, diharapkan mampu meningkatkan pendapatan dan taraf hidup rumah tangga petani. Sehingga dalam pengelolaannya melibatkan seluruh sumberdaya yang ada dalam keluarga, termasuk perempuan. Perempuan menjadi bagian terpenting di sektor pertanian sebagai tenaga kerja, baik pada penyediaan sarana pertanian, budidaya tanaman, pengolahan dan pasca panen hingga pemasaran hasil pertanian (Yuwono, 2013). Setelah adanya perkembangan peran dan posisi kaum perempuan yang sejak dahulu telah menempatkan perempuan sebagai mitra yang sejajar dengan kaum pria, maka fenomena perempuan bekerja pada sektor pertanian bagi masyarakat bukanlah hal yang baru dan bukanlah hal yang tidak mungkin terjadi.

\section{Hortikultura}

Tanaman hortikultura mencakup jumlah spesies yang sangat banyak dan beragam. Jumlah spesies yang sudah dibudidayakan diperkirakan ada sekitar 323 spesies. Di antaranya 80 spesies tanaman sayuran, 60 spesies tanaman buah-buahan, 117 spesies tanaman hias dan 66 spesies tanaman biofarmaka. Di tinjau dari segi kesehatan, tanaman sayuran memainkan peran yang sangat penting karena sayuran merupakan sumber vitamin, mineral, serat dan juga sebagai sumber bahan-bahan yang dapat menyembuhkan penyakit (Wijaya, 2012). Pengembangan hortikultura di Indonesia pada umumnya masih 
dalam skala perkebunan rakyat yang tumbuh dan dipelihara secara alami dan tradisional, sedangkan jenis komoditas hortikultura yang diusahakan masih terbatas. Pada umumnya budidaya hortikultura diusahakan lebih intensif dibandingkan dengan budidaya tanaman lainnya (Ginting, 2015). Indonesia merupakan Negara tropis dengan wilayah cukup luas, dengan variasi agroklimat yang tinggi, merupakan daerah yang potensial bagi pengembangan hortikultura baik untuk tanaman dataran rendah maupun dataran tinggi. Pada umumnya budidaya hortikultura diusahakan lebih intensif dibandingkan dengan budidaya tanaman lainnya (Ginting, 2015).

\section{Konsep Peranan}

Kamus Bahasa Indonesia, pengertian peran adalah sesuatu yang menciptakan bagian yang memegang pimpinan atau kekuasaan terutama dalam terjadinya suatu hal ataupun peristiwa. Levinson (dalam Soekanto, 2009) mengatakan peranan mencakup tiga hal yaitu:

1) Peranan meliputi norma-norma yang dihubungkan dengan posisi atau tempat seseorang dalam masyarakat. Peranan dalam arti ini merupakan rangkaian peraturanperaturan yang membimbing seseorang dalam kehidupan bermasyarakat.

2) Peranan merupakan suatu konsep tentang apa yang dapat dilakukan oleh individu dalam masyarakat sebagai organisasi.

3) Peranan juga dapat dikatakan sebagai perilaku individu yang penting bagi struktur sosial masyarakat.

\section{Peranan Perempuan}

Menurut Sajogyo, P (1979) peranan perempuan dapat di analisis dalam dua cara yaitu: Pertama, Housework (pekerjaan rumah tangga) adalah pekerjaan yang memerlukan curahan tenaga kerja dan waktu, hasilnya bernilaiguna (bukan bernilai pasar), tidak berupah (unpaid family worker), mayoritas dilakukan oleh perempuan. Kedua, pencari nafkah Utama dan tambahan, dalam rumahtangga, antara status dan peran perempuan, dapat dihitung dengan curahan waktu kerja dan pendapatan yang di hasilkan. Konsep yang di kembangkan: (1) Pembagian kerja antara perempuan dan pria, (2) Status perempuan dalam keluarga, rumahtangga, dan masyarakat (3) Relasi antara perempuan dan pria: pembagian kekuasaan dan otoritas (Home production; income and expenditure, input rumahtangga, control atas lahan dan sumberdaya lainnya, peran perempuan dalam pengambilan keputusan). Suami sebagai pencari nafkah kini mulai tergeser fungsinya sebagai pencari nafkah oleh kehadiran isteri/perempuan dimana isteri/perempuan sekarang telah memiliki peran ganda yaitu peran sebagai pencari nafkah dan peran sebagai ibu rumah tangga yang harus meluangkan waktunya untuk keluarga khususnya anak sehingga tercipta ketahanan keluarga. Potensi yang dimiliki perempuan untuk menopang ekonomi keluarga memang cukup besar. Namun demikian perempuan tidak menonjolkan diri atau mengklaim bahwa mereka menjadi penyangga utama ekonomi keluarga (Haryanto, 2008 dalam Hapsari, 2018).

\section{Peran Ganda Perempuan}

Pada dasarnya peran ganda perempuan mempunyai arti dua atau lebih peran atau fungsi yang harus dikerjakan oleh seorang perempuan dalam tempo atau waktu yang bersamaan. peran-peran ini pada umumnya berkaitan dengan peran perempuan dalam ranah domestik, sebagai ibu rumah tangga, serta peran perempuan dalam ranah publik yang biasanya berupa peran perempuan dalam wilayah pekerjaan (tenaga kerja) (Rustiani, 1996).

\section{Pendapatan Perempuan}

Pendapatan perempuan dipengaruhi oleh karakteristik sosial ekonomi yaitu umur, tingkat pendidikan, pengalaman bekerja, jumlah tanggungan dan curahan tenaga kerja. Karena perempuan semakin dituntut peranannya bukan hanya sebagai ibu rumah tangga melainkan juga sebagai orang yang berperan dalam menyumbangkan pendapatan pada keluarga. Kontribusi penghasilan perempuan dalam ekonomi keluarga ialah bagian penghasilan yang disumbangkan perempuan dari seluruh jumlah pendapatan keluarga (Ambarini, 2002 dalam Bertham,dkk, 2011). 


\section{Pendapatan Keluarga}

Menurut Simanjuntak mengatakan bahwa jumlah tanggungan yang tinggi pada suatu rumah tangga tanpa diikuti dengan peningkatan dari segi ekonomi akan mengharuskan anggota keluarga selain kepala keluarga untuk mencari nafkah. Pendapatan keluarga ialah sejumlah penghasilan dari keluarga (penghasilan dari suami, istri, dan anggota keluarga lainnya).

\section{Rumusan Masalah}

Bagaimana peranan perempuan sebagai pencari nafkah dalam keluarga dengan berdagang hortikultura di Kecamatan Modoinding?

\section{Tujuan Penelitian}

Berapa besar peranan perempuan sebagai pencari nafkah dalam keluarga dengan berdagang hortikultura di Kecamatan Modoinding.

\section{Manfaat Penelitian}

Adapun manfaat dari penelitian ini yaitu:

1. Sebagai bahan informasi bagi peneliti dalam mengembangkan wawasan untuk menjadi seorang sarjana.

2. Sebagai bahan referensi dan sumber informasi bagi pihak-pihak yang membutuhkan dalam hal ini penentuh untuk mengambil kebijakan.

\section{METODE PENELITIAN}

\section{Tempat dan Waktu Penelitian}

Penelitian ini dilaksanakan di Modoinding selama 4 bulan yaitu dari bulan Oktober 2019 sampai dengan Januari 2020 mulai dari persiapan sampai penyusunan laporan hasil penelitian.

\section{Metode Pengumpulan Data}

Penelitian ini menggunakan data Primer dan Sekunder. Data Primer diperoleh melalui wawancara langsung pada perempuan pedagang hortikultura, dengan menggunakan daftar pertanyaan yang telah disiapkan berupa kuisoner. Data Sekunder diperoleh dari pustaka, sumber resmi dari instansi terkait, serta sumbersumber lain yang berkaitan dengan penelitian ini.

\section{Metode Pengambilan Sampel}

Pengambilan sampel menggunakan metode purposive sampling yaitu sampel yang diambil secara sengaja, Sampel yang diambil adalah sebanyak 13 responden pedagang perempuan hortikultura yang sudah berkeluarga dan masih mempunyai suami serta merupakan penduduk asli Modoinding sebagai sampel.

\section{Konsep Pengukuran Variabel}

Batasan dari variabel-variabel yang digunakan dalam penelitian ini adalah sebagai berikut:

A. Karakteristik Responden

1. Umur (Tahun)

2. Tingkat pendidikan terakhir

3. Jumlah tanggungan (Orang)

4. Pengalaman berdagang (Tahun)

B. Peran perempuan pedagang hortikultura dalam keluarga di Modoinding

1. Jam kerja perempuan pedagang/hari

2. Pendapatan keluarga (Rp/bulan)

a. Pendapatan suami yaitu pendapatan yang diperoleh dari berbagai pekerjaan yang dijalankan (Rp/bulan).

b. Pendapatan istri yaitu pendapatan ibu rumah tangga yang didapat dari hasil berdagang hortikultura (Rp/bulan).

c. Pendapatan anak yaitu pendapatan dari pria dan wanita yang belum berkeluarga tetapi sudah mempunyai pekerjaan (Rp/bulan).

\section{Metode Analisis Data}

Metode analisis data yang digunakan dalam penelitian ini adalah analisis pendapatan isteri sebagai pedagang hortikultura, suami dan anak. Analisis jam kerja isteri yang disajikan dalam bentuk tabel.

\section{HASIL DAN PEMBAHASAN}

\section{Deskripsi Wilayah Penelitian}

Modoinding merupakan salah satu daerah sentra hortikultura, berjarak sekitar 131,3 km dari Kota Manado, ibukota Provinsi Sulawesi 
Utara. Adapun batas-batas wilayahnya sebagai berikut.

a. Sebelah Timur hutan lindung

b. Sebelah Barat berbatasan dengan Kabupaten Bolaang Mongondow

c. Sebelah Selatan berbatasan dengan Kabupaten Bolaang timur

d. Sebelah Utara berbatasan dengan Kecamatan Maesaan

Pusat perbelanjaan dari wilayah Modoinding berada di Desa Pinasungkulan, dimana para perempuan pedagang hortikultura yang merupakan pedagang pengumpul dan pengecer menjual dagangannya di Desa Pinasungkulan. Kegiatan berdagang para perempuan ini, ada yang berdagang setiap hari tetapi ada juga yang berdagang hanya di hari pasar yaitu senin, rabu dan jumat, ada yang mulai berdagang dari jam 03.00 pagi sampai 20.00 malam. Paling ramai konsumen datang berbelanja sekitaran jam 07.00 sampai jam 10.30. Hortikultura yang didagangkan yaitu jenis sayur-sayuran seperti kentang, kubis, wortel, cabai, tomat dan lain-lain. Para pedagang ini memiliki tenda masing-masing dalam berdagang.

\section{Karakteristik Responden}

\section{Umur Responden}

Faktor umur sangat berkaitan dengan kondisi fisik seseorang, semangat, tenaga serta kemampuannya dalam melakukan suatu pekerjaan. Terlebih lagi jenis pekerjaan yang ada di sektor pertanian membutuhkan kondisi fisik dan tenaga yang kuat. Dengan demikian jika umur perempuan petani masih dalam usia produktif, (usia 16 tahun sampai 60 tahun) maka diharapkan peran sertanya dalam pekerjaan akan mendatangkan kontribusi yang besar pada keuangannya.

Umur para pedagang hortikultura di daerah penelitian bervariasi antara 40 hingga 70 tahun ke atas untuk jenis pekerjaan yang sama yaitu pedagang hortikultura.

\begin{tabular}{cccc} 
Tabel 1. & Responden Menurut Kelompok Umur \\
\hline No & $\begin{array}{c}\text { Umur } \\
\text { (Tahun) }\end{array}$ & $\begin{array}{c}\text { Jumlah } \\
\text { Responden }\end{array}$ & $\begin{array}{c}\text { Persentase } \\
(\%)\end{array}$ \\
\hline 1 & $41-48$ & 4 & 31 \\
2 & $49-55$ & 1 & 8 \\
3 & $56-62$ & 3 & 23 \\
4 & $63-69$ & 2 & 15 \\
5 & $70-76$ & 3 & 23 \\
\hline & Jumlah & $\mathbf{1 3}$ & $\mathbf{1 0 0}$
\end{tabular}

Tabel 1 memperlihat bahwa responden yang berusia 41 tahun sampai dengan 48 tahun berjumlah $31 \%$, 49 tahun sampai dengan 55 tahun berjumlah $8 \%, 56$ tahun sampai 62 tahun berjumlah 23\%, 63 tahun sampai dengan 69 tahun berjumlah $15 \%$, dan responden yang berusia 70 tahun sampai 76 tahun berjumlah $23 \%$.

Dari penelitian ini dapat di ketahui bahwa perempuan pedagang hortikultura di Modoinding yang masih mempunyai suami, di dominasi oleh ibu-ibu yang sudah berusia 56 tahun ke atas, walaupun sudah lanjut usia, tetap melakukan aktivitas setiap hari sebagai pedagang hortikultura.

\section{Pendidikan Responden}

Pendidikan memegang peranan penting dalam usaha menciptakan perubahan-perubahan dalam kehidupan masyarakat. Salah satunya adalah perubahan cara berpikir masyarakat untuk meningkatkan pendapatan keluarga. Semakin tinggi pendidikan diharapkan pola pikir penduduk semakin rasional.

Tabel 2. Tingkat Pendidikan Perempuan Pedagang Hortikultura di Kecamatan Modoinding

\begin{tabular}{cccc}
\hline No & $\begin{array}{c}\text { Tingkat } \\
\text { Pendidikan }\end{array}$ & $\begin{array}{c}\text { Jumlah } \\
\text { Responden }\end{array}$ & $\begin{array}{c}\text { Persentase } \\
(\boldsymbol{\%})\end{array}$ \\
\hline 1 & SD & 7 & 54 \\
2 & SMP & 4 & 31 \\
3 & SMA & 2 & 15 \\
\hline & Jumlah & $\mathbf{1 3}$ & $\mathbf{1 0 0}$ \\
\hline
\end{tabular}

Sumber: Diolah dari Data Primer 2020

Hasil penelitian menunjukkan bahwa tingkat pendidikan perempuan pedagang hortikultura di Modoinding, memiliki tingkat pendidikan terbanyak yaitu $54 \%$ pada tingkat pendidikan Sekolah Dasar (SD), sedangkan 31\% berada pada tingkat pendidikan SMP dan pada tingkat pendidikan SMA hanya mencapai $15 \%$.

Dari penelitian ini dapat di ketahui bahwa untuk menjadi pedagang hortikultura di Modoinding tidak memerlukan pendidikan yang tinggi hanya membutuhkan pengalaman untuk bisa berinteraksi dan menjual segala dagangan dengan baik. 


\section{Jumlah Tanggungan Keluarga}

Jumlah tanggungan merupakan banyaknya orang yang di biayai dalam suatu rumah tangga. Jumlah tanggungan keluarga mempengaruhi pendapatan per kapita. Makin banyak tanggungan suatu keluarga makin besar biaya yang harus dikeluarkan, makin sedikit tanggungan keluarga makin sedikit juga biaya yang dikeluarkan. Tanggungan keluarga merupakan salah satu alasan utama bagi para ibu rumah tangga turut serta dalam membantu suami untuk memutuskan diri untuk bekerja memperoleh penghasilan.

\begin{tabular}{cccc} 
Tabel 3. Jumlah Tanggungan Perempuan & \multicolumn{3}{c}{$\begin{array}{c}\text { Pedagang } \\
\text { Hortikultura } \\
\text { Kecamatan Modoinding }\end{array}$} \\
\hline & $\begin{array}{c}\text { Jumlah } \\
\text { Tanggungan }\end{array}$ & $\begin{array}{c}\text { Jumlah } \\
\text { Responden }\end{array}$ & $\begin{array}{c}\text { Persentas } \\
\text { e (\%) }\end{array}$ \\
\hline No & 0 & 7 & 54 \\
\hline 1 & 0 & 5 & 38 \\
2 & $1-2$ & 1 & 8 \\
3 & $3-4$ & 13 & 100 \\
\hline & Jumlah &
\end{tabular}

Sumber: diolah dari Data Primer 2020

Dari hasil penelitian dapat dilihat bahwa $38 \%$ dari responden mempunyai tanggungan keluarga rata-rata 1 orang sampai dengan 2 orang, $8 \%$ responden mempunyai tanggungan keluarga rata-rata 3 orang sampai dengan 4 orang, dan responden yang tidak mempunyai tanggungan keluarga $54 \%$.

Hal ini menunjukkan bahwa paling banyak responden hanya memiliki 1 sampai dengan 2 tanggungan. Responden yang tidak memiliki tanggungan berjumlah 7 orang, dalam kategori ini 5 anak responden sudah bersuami dan 2 responden tidak mempunyai anak.

\section{Pengalaman Berdagang}

Pengalaman dalam berdagang juga mempengaruhi penghasilan, apabila sudah lama menekuni pekerjaan, pastinya sudah mengetahui hal-hal baik yang dapat dilakukan agar mendapat hasil yang baik pula.
Tabel 4. Pengalaman Usaha Perempuan Pedagang

\begin{tabular}{cccc}
\multicolumn{4}{c}{ Hortikultura di Kecamatan Modoinding } \\
\hline No & $\begin{array}{c}\text { Lama Usaha } \\
\text { (Tahun) }\end{array}$ & $\begin{array}{c}\text { Jumlah } \\
\text { Responden }\end{array}$ & $\begin{array}{c}\text { persentase } \\
(\%)\end{array}$ \\
\hline 1 & $<10$ & 2 & 15 \\
2 & $>10-15$ & 1 & 8 \\
3 & $16-20$ & 2 & 15 \\
4 & $21-25$ & 2 & 15 \\
5 & $26-30$ & 1 & 8 \\
6 & $31-35$ & 2 & 15 \\
7 & $36-40$ & 3 & 23 \\
\hline & Jumlah & 13 & 100 \\
\hline
\end{tabular}

Sumber: Diolah dari Data Primer 2020

Tabel 4 menunjukkan sebanyak 15\% responden menekuni pekerjaan selama kurang dari 10 tahun, kategori ini merupakan pedagang termuda dalam berdagang yaitu selama 8 tahun dengan jumlah 2 responden. 11 sampai dengan 15 tahun tercatat $8 \%$ responden, 16 sampai dengan 20 tahun tercatat $15 \%$ responden, 21 sampai dengan 25 tahun tercatat $15 \%$ responden, 26 sampai dengan 30 tahun tercatat $8 \%$ responden, 31 sampai dengan 35 tahun tercatat $15 \%$ responden, dan yang menekuni pekerjaan selama 36 sampai dengan 40 tahun tercatat $23 \%$ responden, kategori ini merupakan responden yang paling lama dalam berdagang yaitu ada yang 38 tahun dengan jumlah 1 responden dan 40 tahun dengan jumlah 2 responden.

Dengan adanya pengalaman berusaha ini maka akan mempermudah responden untuk mengambil keputusan yang berhubungan dengan usaha pemasaran.

\section{Peran Perempuan Pedagang Hortikultura}

\section{Jam Kerja Berdagang}

Pekerjaan sebagai pedagang hortikultura memakan waktu lebih banyak dari pada jam kerja di sektor formal, hari kerjanya pun tidak beraturan. Para istri harus mampu membagi waktu mereka untuk menjalankan tugas rumah tangga, waktu untuk mengurus anak dan tugas mereka untuk mencari nafkah tambahan. 
Tabel 5. Jam Kerja Perempuan Pedagang Hortikultura di Kecamatan Modoinding

\begin{tabular}{cccc}
\hline No & $\begin{array}{c}\text { Waktu Kerja } \\
\text { (Jam/Hari) }\end{array}$ & $\begin{array}{c}\text { Jumlah } \\
\text { Responden }\end{array}$ & $\begin{array}{c}\text { Persentase } \\
(\%)\end{array}$ \\
\hline 1 & $<10$ & 4 & 31 \\
2 & $>10-12$ & 2 & 15 \\
3 & $13-15$ & 5 & 38 \\
4 & $>16$ & 2 & 15 \\
\hline & Jumlah & 13 & 100 \\
\hline
\end{tabular}

Sumber: Diolah dari Data Primer 2020

Tabel 5 menunjukkan responden yang mempunyai jam kerja kurang dari 10 jam sehari tercatat 31\%. 10 sampai dengan 12 jam sehari tercatat $15 \%$, selanjutnya $38 \%$ responden bekerja selama lebih dari 13 sampai dengan 15 jam sehari. Dan 15\% responden menghabiskan waktu lebih dari 16 jam dalam sehari. Waktu kerja perempuan pedagang hortikultura yang terendah itu hanya 8 jam per hari, sedangkan yang tertinggi yaitu 17 jam per harinya.

Responden yang berdagang setiap hari dengan waktu di atas 14 jam, mengatakan bahwa sedikit waktu yang bisa mereka pakai untuk beristirahat dan melakukan kegiatan lain. Mereka menggunakan waktu untuk makan dan beristirahat ketika dagangan mereka lagi sepi/tidak ada pembeli. apabila ada keperluan/kegiatan yang memungkinkan untuk mereka meninggalkan dagangan seperti (ibadah, arisan, dll) yang hanya menghabiskan waktu 1 sampai dengan 2 jam untuk meninggalkan dagangan merekamaka ada anak yang pulang sekolah atau suami mereka yang sudah menyelesaikan pekerjaan lain atau suami tidak bekerja, menggantikan untuk berdagang sementara, namun bantuan suami dan anak tidak di hitung sebagai pendapatan. Berbeda dengan responden yang hanya menghabiskan waktu berdagang setiap senin, rabu, jumat dengan waktu dibawa 14 jam, mereka mempunyai waktu untuk keluarga dan waktu kegiatan lainnya.

\section{Pendapatan Keluarga}

Total pendapatan keluarga didapat dari pendapatan suami, istri, dan pendapatan anak yang sudah bekerja dan belum menikah. Masingmasing anggota keluarga memegang peranan dalam meningkatkan pendapatan guna perbaikan kesejahteraan keluarga. Pendapatan dari masingmasing anggota keluarga selanjutnya akan dijelaskan oleh tabel-tabel berikut ini.
Table 6. Pendapatan Perempuan Pedagang Hortikultura di Kecamatan Modoinding

\begin{tabular}{clcc}
\hline No & $\begin{array}{l}\text { Pendapatan } \\
(\text { Rp/bulan) }\end{array}$ & $\begin{array}{c}\text { Jumlah } \\
\text { Responden }\end{array}$ & $\begin{array}{c}\text { Persentase } \\
(\%)\end{array}$ \\
\hline 1 & $<2.000 .000$ & 3 & 23 \\
& $2.000 .001-$ & & \\
2 & 2.500 .000 & 2 & 15 \\
& $2.500 .001-$ & 2 & 15 \\
3 & 3.000 .000 & 3 & 23 \\
& $3.000 .001-$ & & \\
4 & 3.500 .000 & 2 & 15 \\
& $3.500 .001-$ & 1 & 8 \\
5 & 4.000 .000 & $\mathbf{1 3}$ & $\mathbf{1 0 0}$ \\
6 & $>4.000 .001$ & & \\
\hline & Jumlah &
\end{tabular}

Sumber: Diolah dari Data Primer 2020

Berdasarkan data yang tersaji dalam Tabel, sebanyak $23 \%$ yang memiliki pendapatan kurang dari Rp. 2.000.000 sebulan. Pendapatan di atas Rp. 2.000.0001 sampai Rp. 2.500.000 sebulan tercatat sebanyak $23 \%$. Selanjutnya pendapatan lebih dari Rp. 2.500.001 sampai Rp. 3.000 .000 tercatat $15.4 \%$. Pendapatan Rp. 3.000.001 sampai Rp. 3.500.000 tercatat 23.1\%, dan pendapatan Rp. 3.500.001 sampai Rp. 4.000.000 tercatat sebanyak $15 \%$. Pendapatan lebih dari Rp. 4.000.001 tercatat hanya $8 \%$.

Pendapatan perempuan pedagang hortikultura di atas Rp. 3.000.001 itu menghabiskan waktu lebih dari 14 jam tiap harinya atau hanya tiap hari pasar (senin, rabu dan jumat), sedangkan pendapatan dibawah Rp. 3.000.000 hanya menghabiskan waktu kurang dari 14 jam atau paling rendahnya 8 jam tiap hari pasar (senin, rabu dan jumat). Dalam berdagang, ada responden yang sudah memiliki langganan pembeli sehingga responden sudah bisa mengetahui seberapa banyak dagangannya yang akan habis. Langganan pembeli juga berpengaruh terhadap pendapatan responden. Pendapatan di atas Rp. 3.000.001 juga dikarenakan langganan para responden, tetapi ada juga karena jenis sayuran yang banyak di jual responden.

Responden tidak memiliki pendapatan diluar dari pekerjaan sebagai pedagang hortikultura karena mereka tidak memiliki pekerjaan sampingan. Pendapatan responden diakuinya digunakan untuk keperluan rumah tangga mulai dari kebutuhan makan setiap hari, sekolah anak, tabungan sampai kebutuhan lainnya. 
Tabel 7. Pekerjaan Suami

\begin{tabular}{|c|c|c|c|}
\hline No & $\begin{array}{c}\text { Pekerjaan } \\
\text { Suami }\end{array}$ & $\begin{array}{l}\text { Jumlah } \\
\text { (Orang) }\end{array}$ & $\begin{array}{c}\text { Persentase } \\
(\%)\end{array}$ \\
\hline & Tidak & & \\
\hline 1 & Bekerja & 4 & 31 \\
\hline 2 & Petani & 5 & 38 \\
\hline 3 & $\begin{array}{c}\text { Buruh Tani } \\
\text { Penarik }\end{array}$ & 1 & 8 \\
\hline 4 & Bentor & 2 & 15 \\
\hline \multirow[t]{2}{*}{5} & Tibo & 1 & 8 \\
\hline & Jumlah & 13 & 100 \\
\hline
\end{tabular}

Sumber: diolah dari Data Primer 2020

Tabel 7 menunjukkan sebanyak 38\% suami bekerja sebagai petani, $8 \%$ bekerja sebagai buruh tani dan tibo, $15 \%$ bekerja sebagai penarik bentor dan yang tidak bekerja tercatat sebanyak $31 \%$.

Suami yang bekerja sebagai petani merupakan petani hortikultura yamg masa panennya 3 sampai dengan 4 bulan, dan suami yang bekerja sebagai tibo juga merupakan pedagang hortikultura tetapi bedanya suami membawah dagangannya di luar Modoinding, berbeda dengan istri yang hanya berdagang di Modoinding. Antara istri pedagang hortikultura dan suami sebagai tibo, mereka mencari dagangan mereka bersama dengan menyesuaikan seberapa banyak yang akan di dagangkan suami dan istri nantinya. Suami yang bekerja sebagai buruh tani menghabiskan waktu kerja sebanyak 7 jam per hari dengan waktu istirahat 1 jam, waktu kerja dimuali dari jam 06:00 - 12:00 wita. Pada tabel ini juga tercatat ada $31 \%$ suami yang tidak memiliki pekerjaan, satu di antaranya sakit dan tiganya dikarenakan faktor usia, sehingga hanya membantu istri di pasar dalam berdagang.

Tabel 8. Pendapatan Suami

\begin{tabular}{cccc}
\hline No & $\begin{array}{c}\text { Pendapatan } \\
\text { (Rp/bulan) }\end{array}$ & $\begin{array}{c}\text { Jumlah } \\
\text { (Orang) }\end{array}$ & $\begin{array}{c}\text { Persentase } \\
(\boldsymbol{\%})\end{array}$ \\
\hline 1 & Tidak bekerja & 4 & 31 \\
2 & $<5.000 .000$ & 4 & 31 \\
& $>5.000 .000-$ & & \\
3 & 10.000 .000 & 4 & 31 \\
4 & $>10.000 .00$ & 1 & 8 \\
\hline & Jumlah & $\mathbf{1 3}$ & $\mathbf{1 0 0}$ \\
\hline
\end{tabular}

Sumber: diolah dari Data Primer 2020
Tabel 8 menunjukkan sebanyak $31 \%$ memiliki pendapatan kurang dari Rp. 5.000.000 sebulan. Umumnya suami pada kelas ini bekerja sebagai buruh tani dengan upah per hari Rp. 100.000 , penarik bentor dengan penghasilan Rp. 100.000 sampai Rp. 200.000 untuk satu hari, dan tibo dengan pendapatan Rp. 3.000.000 sampai Rp. 4.000.000 perbulan. Selanjutnya suami dengan pendapatan 5.000.000 sampai 10.000 .000 per 3 sampai 4 bulan tercatat sebanyak $31 \%$, dan pendapatan di atas 10.000 .000 per 3 sampai 4 bulan tercatat hanya $8 \%$. Suami pada kelas ini bekerja sebagai petani hortikultura.

Pendapatan responden (istri) di bandingkan dengan pendapatan suami. Pendapatan yang lebih banyak itu dihasilkan dari pendapatan istri sebagai pedagang meskipun waktu yang digunakan istri lebih banyak dibandingkan dengan suami. Jadi dapat di katakan bahwa istri itu sebagai pencari nafkah utama dalam keluarga.

Tabel 9. Pekerjaan Anak

\begin{tabular}{cccc}
\hline No & Pekerjaan Anak & $\begin{array}{c}\text { Jumlah } \\
\text { (Orang) }\end{array}$ & $\begin{array}{c}\text { Persentase } \\
(\mathbf{\%})\end{array}$ \\
\hline 1 & Petani & 1 & 20 \\
2 & Buruh Tani & 2 & 40 \\
3 & Tibo & 1 & 20 \\
4 & Pegawai Swasta & 1 & 20 \\
\hline & Jumlah & $\mathbf{5}$ & $\mathbf{1 0 0}$ \\
\hline
\end{tabular}

Sumber: Diolah dari Data Primer 2020

Tabel 9 menunjukkan bahwa anak yang bekerja sebagai petani tercatat 20\%, bekerja sebagai buruh tani tercata $40 \%$, bekerja sebagai tibo tercatat $20 \%$ dan anak yang bekerja sebagai pegawai swasta tercatat $20 \%$.

Anak yang bekerja sebagai buruh tani menghabiskan waktu kerja sebanyak 7 jam per hari dengan waktu istirahat 1 jam, waktu kerja dimuali dari jam 06:00 - 12:00 WITA. Anak yang bekerja sebagai pegawai swasta menghabiskan waktu kerja sebanyak 8 jam per hari dengan waktu istirahat 1 jam, waktu kerja dimulai dari jam 08:00 - 16:00 WITA. 
Usia anak yang bekerja sudah pada usia produktif, yang bekerja sebagai pegawai swasta lulusan SMA, sedangkan anak yang pekerjaannya sebagai petani, buruh tani dan tibo berumur di atas 17 tahun dan merupakan anak laki-laki. Pendapatan anak dari tibo yaitu hasil dari membantu ayahnya yang juga sebagai tibo dengan menjadi supir.

Tabel 10. Pendapatan Anak

\begin{tabular}{cccc}
\hline No & Pendapatan Anak & $\begin{array}{c}\text { Jumlah } \\
(\text { Orang) }\end{array}$ & $\begin{array}{c}\text { Persentase } \\
(\mathbf{\%})\end{array}$ \\
\hline \multirow{2}{*}{1} & $1.000 .000-$ & & \\
& 2.000 .000 & 3 & 60 \\
2 & $2.000 .001-$ & & \\
& 3.000 .000 & 1 & 20 \\
3 & $3.000 .001-$ & & - \\
& 4.000 .000 & - & \\
4 & $4.000 .001-$ & & 20 \\
\hline & 5.000 .000 & 1 & $\mathbf{1 0 0}$ \\
\hline
\end{tabular}

Sumber: Diolah dari Data Primer 2020

Tabel 10 memperlihatkan pendapatan anak yang belum menikah. Tercatat $60 \%$ anak dengan pendapatan kurang dari Rp. 2.000.000 yang di dapat dari pekerjaannya sebagai buruh tani dan tibo, pada kelas ini anak yang pekerjaannya sebagai buruh tani menghasilkan upah Rp. 100.000 per hari. Pendapatan lebih dari Rp. 2.000.001 sampai Rp. 3.000.000 sebulan tercatat sebanyak $20 \%$, yang di dapat dari pekerjaannya sebagai pegawai swasta. Dan pendapatan di atas 4.000.001 sebulan tercatat $20 \%$, di dapat dari pekerjaannya sebagai petani.

\section{KESIMPULAN DAN SARAN}

\section{Kesimpulan}

Berdasarkan penelitian maka dapat disimpulkan bahwa peran perempuan sebagai pencari nafkah dalam keluarga dengan berdagang hortikultura di Kecamatan Modoinding, dapat menambah perekonomian dalam keluarga dengan pendapatan $\mathrm{Rp}$. 1.500.000 sampai dengan Rp. 5.500.000/bulan, menghabiskan waktu 8 jam sampai dengan 17 jam/hari. Pendapatan yang lebih banyak itu dihasilkan dari pendapatan istri sebagai pedagang dengan waktu yang digunakan istri lebih banyak dibandingkan dengan suami. Jadi dapat di katakan bahwa istri itu sebagai pencari nafkah utama dalam keluarga. Ditemukan $60 \%$ anak dengan pendapatan kurang dari Rp. 2.000.000,Pendapatan lebih dari Rp. 2.000.001 sampai Rp. 3.000.000 sebulan sebanyak 20\%, pendapatan di atas 4.000.001 sebulan sebanyak $20 \%$.

\section{Saran}

Perempuan yang bekerja sebagai pedagang hortikultura untuk menambah perekonomian dalam keluarga, harus juga tetap memperhatikan peran mereka di rumah tangga sebagai seorang ibu dan seorang istri. Serta memperhatikan waktu kerja karena dapat berpengaruh pada kesehatan.

\section{DAFTAR PUSTAKA}

Astuti, W.W.A. 2013. Peran Ibu Rumah Tangga Dalam Meningkatkan Kesejahteraan Keluarga. Skripsi. Fakultas Ilmu Pendidikan Universitas Negri Semarang. Semarang.

Bertham, Y.H. 2011. Peranan Perempuan Dalam Perekonomian Keluarga Dengan Memanfaatkan Sumberdaya Pertanian. Jurnal AGRISEP. Jurusan Sosial Ekonomi Pertanian Fakultas Pertanian Universitas Bengkulu. Bengkulu.

Ginting, T. 2015. Dampak Terapan Media Komunikasi Pada Usahatani Hortikultura Dikelurahan Rurukan. Fakultas Pertanian Universitas Sam Ratulangi. Skripsi. Manado.

Hapsari, A 2018. Kontribusi Pendapatan Pedagang Perempuan Dalam Ekonomi Rumah Tangga. Jurnal. Departemen Sains Komunikasi Dan Pengembangan Masyarakat Fakultas Ekologi Manusia Institut Pertanian Bogor. Bogor.

Husodo, dkk, 2004. Pertanian Mandiri. Pandangan Strategis Para Pakar untuk Kemajuan Petani Indonesia. Penebar Swadaya. Jakarta. 
Irawan. 2012. Agribisnis Hortikultura: Peluang dan Tantangan Dalam Era Perdagangan Bebas. Jurnal Pusat Penelitian dan Pengembangan Sosial Ekonomi Pertanian. Bogor.

Luhfi, A. 2010. Akses dan Kontrol Perempuan Petani Penggarap Pada Lahan Pertanian PTPN IX Kebun Merbuh. Jurnal Komunitas. Jurnal Sosiologi dan Antropologi, Fakultas Ilmu Sosial, Universitas Negeri Semarang. Semarang.

Raho. Bernard, 2007. Teori Sosiologi Modern. Prestasi Pustakarya. Jakarta.

Rustiani, F. 1996. Istilah-Istilah Umum dalam Wacana Gender. Dalam Jurnal Analisis Sosial: Analisis Gender dalam Memahami Persoalan Perempuan. Yayasan Akatiga. Bandung.

Sajogyo, P. 1979. Peranan Perempuan dalam Keluarga dan Pembangunan Desa di Indonesia.
Simanjuntak, P. J. 2001. Pengantar Ekonomi Sumber Daya Manusia Edisi Kedua. Lembaga Penerbit Fakultas Ekonomi Universitas Indonesia. Jakarta.

Soekanto, S. 2009. Peranan Sosiologi Suatu Pengantar. Edisi Baru, Rajawali Pers, Jakarta.

Wijaya, K.M., 2012. Pengantar Agronomi Sayuran. Prestasi Pustaka

Wisadirana, D. 2004. Sosiologi Pedesaan. UMM Press. Malang.

Yuwono, Dian M. 2013. Pengarusutamaan Gender Dalam Pembangunan Pertanian: Kasus Pada Pelaksanaan Program Feati Di Kabupaten Magelang. Badan Pengkajian Teknologi Pertanian. Jawa Tengah.

Zulkarnain, 2014. Dasar-Dasar Hortikultura. PT Bumi Aksara. Jakarta. 